\title{
Valuing improvements in the water rights system in South Africa, a contingent ranking
} approach

Stijn Speelman ${ }^{a^{*}}$, Stefano Farolfi ${ }^{\mathrm{b}}$, Aymen Frija $^{\mathrm{c}}$, Guido Van Huylenbroeck ${ }^{\mathrm{d}}$

${ }^{a}$ Postdoctoral researcher, Department of Agricultural Economics, Ghent University

${ }^{\mathrm{b}}$ Professor, CIRAD, UMR G Eau and International Center for Water Economics and Governance in Africa (IWEGA), University of Maputo, Mozambique

${ }^{c}$ Postdoctoral researcher, Department of Agricultural Economics, Ghent University

${ }^{a}$ Professor, Department of Agricultural Economics, Ghent University

KEY TERMS: contingent ranking, water rights, South Africa, willingness to pay, irrigation, water policy, water allocation, water resources economics

\begin{abstract}
In the context of increasing water scarcity, understanding is growing that irrigation water rights are important and that a lack of effective water rights systems constitute a major reason for inefficient water management. This study carried out a contingent ranking experiment to study how smallholder irrigators in South Africa would value potential changes in water rights. Three specific dimensions of water rights, relevant for the South African case, are considered: duration, quality of title and transferability. Results indicate that smallholder irrigators are prepared to pay considerably higher water prices if improvements are made in the water rights system. This implies that the proposed interventions in the water rights system would improve the efficiency and productivity of the smallscale irrigation sector. The increased willingness to pay could furthermore also assist South African government to reach the objective of increased cost recovery.
\end{abstract}

\footnotetext{
* Corresponding author: Stijn Speelman, Department of Agricultural Economics, Coupure Links 653, 9000 Gent, Belgium (Stijn.speelman@ugent.be)
} 


\section{Introduction}

There is general agreement that if property rights are ill-defined, this can seriously impair the efficient use of natural resources (Randall, 1978; Ostrom, 2000; Heltberg, 2002; Linde-Rahr, 2008). As indicated by Challen (2000), this is linked to the transaction costs associated with the making of decisions over the use of the resource. When property rights are ill-defined, this creates high transaction costs, limits the value people assign to a resource and confines the incentives for resource users to manage a resource sustainably. Improvements in the property rights system for a resource will increase the willingness to pay (WTP) by the resource users for its use because transaction costs are reduced (Herrera et al., 2004; Frija et al., 2008) or investments made more profitable (Bruns, 2003). Therefore sub-optimal property right systems constitute a form of inefficiency, which can be revealed by measuring WTP for improvements in their definition. Based on this some authors (e.g., Herrera et al., 2004; Frija et al., 2008; Linde-Rahr, 2008) have recently used classic contingent valuation methods for the evaluation of the degree of the efficiency of a prevailing property right structure.

As an alternative, this study proposes to use contingent ranking (CR), a form of choice modeling. CR is a survey-based technique for modeling preferences for goods, where goods are described in terms of their attributes and the level these take. Respondents are presented with alternative descriptions of a good, differentiated by their attribute levels, and are asked to rank the alternatives. By including price as one of the attributes, WTP can be indirectly calculated from people's rankings (Hanley et al., 2001; Street et al., 2005). Recently choice modeling has often been used to value environmental programs because such programs typically consist of several components and the technique enables to value not only an intervention as a whole, but also its various components (see Hanley et al., 2001; Bateman et al., 2006; Hanley et al., 2006; Burton, 2007). People's WTP for the individual components of an intervention can thus be provided. In our study we use this feature of the method to separately value several water right dimensions. As indicated by Rigby et al. (2010), this would be difficult to do in a CV study. Another advantage of CR is the avoidance of an explicit elicitation of 
respondents' WTP by relying instead on the ranking of a series of alternative packages of characteristics (Foster and Mourato, 2002; Bateman et al., 2006). Compared with ordinary choice experiments, $\mathrm{CR}$ is a relative informational efficient method, with the gains in estimation efficiency yielding significantly narrower confidence intervals on derived WTP measures, thus enhancing the reliability of the mean WTP estimates (MacKenzie, 1993; Holmes and Adamowicz, 2003; Alriksson and Öberg, 2008). Possible problems in using the method are the complex nature of the statistical design, the selection of the appropriate attributes and levels and the cognitive difficulty associated with ranking choices (Hanley et al., 1998, 2001). Finally it should be noted that the method relies on a hypothetical ranking and not on observed behavior.

In this study we use CR to economically value the benefits of improvements in the definition of the current water rights system in South Africa, focusing on smallholder irrigators. Because like environmental programs, water rights interventions usually consist of several components, e.g. changes in transferability, duration or enforcement, CR is an interesting method. In South Africa the National Water Act (Republic of South Africa, 1998) formally replaced the previous system of water rights and entitlements, which were based on the ownership of riparian land, with a new system of administrative limited-period and conditional authorizations to use water (Nieuwoudt, 2002). However, various aspects of this new water rights system have already been criticized. It is therefore relevant to study potential improvements in the system. Moreover, given their apparent low efficiency of water use (Speelman et al., 2008a), the problems of cost-recovery of government investments in these schemes (Perret and Geyser, 2007; Backeberg, 2006) and their political importance a focus on smallholder irrigators is appropriate in the South African context. On one hand the improvements in the definition of water rights can stimulate smallholders to use water more productively, encouraging cooperation and investment (Bruns, 2003, 2007); on the other hand government can benefit from the higher willingness to pay for water by charging higher water prices and thus improve cost recovery (Virjee and Gaskin, 2005). 


\section{Methodology}

\section{Analytical Framework}

The econometric analysis of data collected from a CR experiment is based on McFadden's conditional logit model, which is grounded in the random utility framework (McFadden, 1974). This is presented in Equation (1).

$\mathrm{U}_{\mathrm{ij}}=\mathrm{b}\left(\mathrm{X}_{\mathrm{ij}}, \mathrm{Z}_{\mathrm{i}}\right)+\varepsilon_{\mathrm{ij}}$

Here $\mathrm{U}_{\mathrm{ij}}$ is the utility a person i receives from choosing alternative $\mathrm{j}$. This can be decomposed in two parts: an observable element $b\left(\mathrm{X}_{\mathrm{ij}}, \mathrm{Z}_{\mathrm{i}}\right)$, which describes the preferences of person $\mathrm{i}$ as a function of the attributes of the alternatives presented to the individual $\left(\mathrm{X}_{\mathrm{ij}}\right)$ and the characteristics of the individuals $\left(\mathrm{Z}_{\mathrm{i}}\right)$ and secondly a stochastic element $\left(\varepsilon_{\mathrm{ij}}\right)$, which represents those influences on individual choice that cannot be observed by the researcher (Foster and Mourato, 1997; Blamey et al., 1999).

Typically it is assumed that the $\varepsilon_{\mathrm{ij}}$ are independently and identically distributed with an extreme-value (Weibull) distribution, resulting in a conditional logit model. The probability of one option being chosen over another can be written as in Equation (2)

$$
\mathrm{P}\left(\mathrm{U}_{\mathrm{ik}}>\mathrm{U}_{\mathrm{il}}, \forall \mathrm{k} \neq \mathrm{l}\right)=\frac{\exp \left(b X_{i k}\right)}{\sum_{j} \exp \left(b X_{i j}\right)}
$$

The conditional logit model only allows the identification of the most preferred alternative and does not fully exploit all the information contained in the CR experiment. Beggs et al. (1981) therefore developed an extension to the basic conditional logit model, which is capable of not only identifying the most preferred alternative but also the exact ordinal ranking of all of the remaining elements. This model is known as the rank-ordered logit model. The rank-ordered logit model relies on the repeated application of the conditional logit specification to the set of alternatives remaining after successive first choices have been eliminated from the available options (Hanemann and Kanninen, 1999; Foster 
and Mourato, 2002). Recent applications of the rank-ordered logit model in other fields include studies by Nixon et al. (2009) and Paudel et al. (2007). In the model the probability of obtaining a particular ranking can be expressed as shown in Equation (3) (Hanemann and Kanninen, 1999).

$\mathrm{P}\left(\mathrm{U}_{\mathrm{i} 1}>\mathrm{U}_{\mathrm{i} 2} \quad \ldots>\mathrm{U}_{\mathrm{iJ}}\right)=\prod_{j=1}^{J} \frac{\exp \left(b X_{i j}\right)}{\sum_{k=j}^{J} \exp \left(b X_{i k}\right)}$

The model in Equation (3) does not allow preferences to vary across individuals in accordance with their socio-economic characteristics. Individual specific variables can however be entered in the utility function in interaction form with attributes that change across the alternatives to be ranked (Foster and Mourato, 1997; Blamey et al., 1999). The coefficients obtained for these interaction terms permit to evaluate the effect of socio-economic characteristics on the ranking.

Once the parameter estimates have been obtained, the WTP can be derived for each attribute (Hanley et al., 2001). When it is assumed that utility is a linear function of the attribute levels like in Equation (1), WTP can simply be expressed as in Equation (4):

$W T P=\frac{-b_{c}}{b_{y}}$

where $b_{y}$ is the coefficient of the cost attribute and $b_{c}$ is the coefficient of any of the attributes. Equation 4 corresponds with the marginal rate of substitution between the price attribute and the other attribute in the equation and is called the implicit price.

\section{Application of the contingent ranking experiment}

Typically the design of a choice experiment involves a number of key stages (Hanley et al., 1998; Bennett and Adamowicz, 2001; Holmes and Adamowicz, 2003). First the problem at hand has to be 
clearly characterized. Then the attributes and their levels should be chosen. Researchers must be careful that the attribute space is constructed such that it is relevant for the policy questions being asked. Finally, experimental design procedures are used to construct the choice tasks that will be presented to the respondents. The next paragraphs discuss the implementation of these steps for this study.

\section{Characterization of the problem}

Internationally there is growing understanding that water rights are important and that a lack of effective water rights systems creates major problems for the management of increasingly scarce water supplies (Matthews, 2004; Bruns et al., 2005a). Nevertheless, better information is needed on the gains of changes in water rights systems (Bruns, 2003). This study evaluates the recently revised water rights system in South Africa, with specific reference to smallholder irrigators. The system now legally consists of administrative limited-period and conditional authorizations to use water, which are called licenses (Nieuwoudt, 2002). Except for the fundamental right of access to water for basic human needs, all other water uses require a licence (Stein, 2005). The issuing of licenses to existing and potential new water uses is an ongoing process in South Africa and licenses are introduced gradually in the different parts of the country depending on the degree of water scarcity (DWAF, 2004). In practice the responsible water management authority issues a notice calling for license applications, after which users and prospective users should prepare and submit such applications. In theory the Catchment Management Agency (CMA) will be responsible for authorizing water use, however till the CMA is fully operational regional offices of the Department of Water Affairs (DWAF) are entrusted with this task. The licenses in South Africa have following characteristics (DWAF, 2004):

- they are specific to the user to whom they are issued and to a particular property or area;

- they are specific to the use or uses for which they are issued;

- $\quad$ they are valid for a specified time period, which may not exceed 40 years;

- a range of conditions can be attached to the license (conditions can refer for example to the volumes and timing of abstractions, the volume that may be stored etc...) and

- $\quad$ they must be reviewed by the responsible authority at least every five years. 
Several aspects of this new water rights system have already been criticized. Based on farmers opinions Backeberg (2006) for instance discussed the negative effect of the short review period of the licenses on the investment decisions of farmers, while Nieuwoudt and Armitage (2004) pointed out that the reliability of allocations is highly variable since no assurance of supply or quality is given. Louw and Van Schalkwyk (2002) warned that, for trade in water rights to be potentially successful, transaction costs should be kept low, which might not be the case under the current conditions. Given the reported problems it is therefore relevant to investigate where changes in the system are required and which changes would have the largest impact.

\section{Design of the attribute space}

An influential approach to analyze rights to natural resources categorizes six dimensions: duration, exclusivity, quality of title, flexibility, transferability and divisibility of rights (Scott, 1989). Such subdivision highlights how attributes of rights may be adjusted separately along various dimensions, specifying rights (and implicitly leaving other attributes of rights undefined). As was shown by Challen (2000), Bruns (2006) and Crase and Dollery (2006), this deconstruction can also be applied to water rights. In this work the definition of Crase and Dollery (2006) for the six dimensions is used: Duration is used to represent the period of the rights. Exclusivity describes the extent to which others can be prevented from accessing the item/resource or enjoying the benefits that flow from it. The transferability dimension encapsulates the ease with which a right may be passed to others. Divisibility depicts the degree to which the right can be subdivided and flexibility defines the extent to which the right permits an alteration to the pattern of use. Finally, the quality of title attribute encompasses the capacity of the title to adequately describe the resource or item.

From these six dimensions only the most relevant for the case of South Africa were included in order to keep the size of the CR experiment within manageable proportions. Based on literature review and expert knowledge duration, transferability and quality of title were selected because some degree of attenuation is reported for these dimensions (see Perret, 2002; Nieuwoudt, 2002; Louw and Van Schalkwyk, 2002; Nieuwoudt and Armitage, 2004; Gillit et al., 2005; Backeberg, 2006; Pott et al., 2009). It is hereby assumed that the fact that there is no criticism on the other dimensions implies that these at present are already fairly efficient and that changing them therefore is not a policy priority. 
In terms of duration the National Water Resources Strategy Paper of South Africa (DWAF, 2004) foresees a water license with a specified duration of maximum 40 years. However, this license has to be evaluated at least every 5 years. At each evaluation conditions attached to licenses may change. This procedure should allow the government to take timely measures to maintain the integrity of the water resource, achieve a balance between available water and water requirements, or accommodate changes in water use priorities (DWAF, 2004) This 5-yearly revision will clearly influence investment decisions of farmers, as they might perceive licenses to be insecure (Nieuwoudt and Armitage, 2004; Backeberg, 2006). Levels for the duration in this study are therefore set at 5 years, which is considered as base situation, and 10 years. The 10 years level was chosen here because this is considered long enough not to deter most investments, while still allowing government to respond relatively quickly to changing circumstances.

Transferable water rights and water markets are believed to improve water productivity because they induce transfers of water to users with the highest marginal return (Rosegrant and Binswanger, 1994; Easter et al., 1998; Nieuwoudt and Armitage, 2004; Bruns and Meinzen-Dick, 2005; Gillit et al., 2005; Zekri and Easter, 2007). In South Africa in the National Water Act provisions are made regarding transferability, it is stated that permanent transfers, constituting trade in water licenses, will be subject to all requirements for license applications. This means that the Catchment Management Agency has to approve every transfer. One of the criteria that will be used in the evaluation is that a balance should be maintained between the interest of the parties involved in the trade and the general public interest (DWAF, 2004). For transfers of water rights among irrigators in a same irrigation scheme this type of administrative procedure seems to create unnecessary transaction costs and insecurity. Rosegrant et al. (1995), Shi (2006) and Donohew (2009) point out that this type of overregulation will limit efficiency gains from water transfer. In addition, legislation is not very clear about the timing of the introduction of trade in water licenses (Perret, 2002; Backeberg, 2006). It was therefore also considered relevant to include the current situation where water rights are not transferable as base option in the experiment. This results in three levels regarding transferability 
being introduced in the experiment: no possibility to transfer, administrative transfer and market transfer.

The dimension of quality of title encompasses the capacity of the title to adequately describe a resource or an item. In this respect an important aspect of the water licenses in South Africa is that although quantities will be specified in the license, they are not guaranteed (Republic of South Africa, 1998); this clearly decreases the reliability of the water allocations (Nieuwoudt and Armitage, 2004). For this dimension therefore non-guaranteed and guaranteed supply were chosen as levels in this study.

Finally, to be able to economically value the considered attribute changes, a payment vehicle has to be included. Here we use the unit price of water $\left(\mathrm{R} / \mathrm{m}^{3}\right)$ to evaluate respondent's willingness to pay for the changes in the different attributes. The price attribute is set at three levels $0.06 \mathrm{R} / \mathrm{m}^{3}, 0.09$ $\mathrm{R} / \mathrm{m}^{3}$ and $0.12 \mathrm{R} / \mathrm{m}^{3}$. Average exchange rate at the time of data collection was $1 \mathrm{Rand}=0.13 \mathrm{US} \$$. The price of $0.06 \mathrm{R} / \mathrm{m}^{3}$ corresponds to the order of magnitude of the water prices in the study area (DWAF, 2008b; DWAF, 2008c). Because it is expected that the value attached to the improvements will only capture part of the value of water, the range is also well below most estimations of the productive value of water, which usually is more than $0.5 \mathrm{R} / \mathrm{m}^{3}$ (Speelman et al., 2008b). Table 1 provides an overview of the attributes and attribute levels considered.

\section{INSERT TABLE 1 ABOUT HERE}

\section{Design of the ranking sets}

All possible combinations of four attributes, two with two different levels and two with three different levels produce 36 water right definitions. This is called a full factorial design. Clearly, it would not be feasible to ask respondents to rank the full set of 36 options from most to least preferred. Consequently, it was necessary to find some means of grouping the options into smaller sets (Foster and Mourato, 1997; Bennet and Adamowicz, 2001; Alriksson and Öberg, 2008). This was done in three stages as described below and illustrated in figure 1. 


\section{INSERT FIGURE 6.1 ABOUT HERE}

In the first stage an orthogonal design was constructed using the Orthoplan-function in SPSS. Such orthogonal design allows isolating the effects of individual attributes on the choice, also called the main effects. This ability to "design in" orthogonality is an important advantage over revealed preference random utility models, where attributes in reality are often found to be highly correlated with each other. In our case the orthogonal design resulted in nine options.

Because ranking nine options was still considered a difficult task, it was decided to limit the number of options to be ranked against each other to four. To construct an optimal design with a set of four options a procedure developed by Street et al. (2005) is used. This design procedure results in a design with desirable structural properties such as minimum attribute-level overlap and balance, allowing more information to be gathered from the same sample (Burgess and Street, 2005; Street et al., 2005). Because of these properties the technique has proved to always give an optimal or nearoptimal design for the estimation of main effects, and near-optimal designs for the estimation of main effects plus two-factor interaction effects. The basic idea of the construction technique is simple: the options from the orthogonal design will represent the first option in the choice sets; then a systematic set of level changes is applied to obtain the second option in the choice sets; and another systematic set of changes is applied to get the third option, and so on. In this way, starting from the orthogonal design, nine choice sets with four options in each of them were obtained. The resulting designs are optimal because they have a maximum determinant for the Fisher information matrix. This characteristic is called D-optimality. For more into depth information regarding the design technique see Burgess and Street (2005) or Street et al. (2005). Following Holmes and Adamowicz (2003), it was decided to divide the choice sets in blocks to avoid the respondents' fatigue effect, which could cause consistency to decrease. Each respondent is then assigned randomly to a particular block. This resulted in three blocks with three choice sets in each. Finally, because part of the respondent population was expected to be illiterate, a graphical representation of the attribute levels was used. An example of a choice set is presented in figure 2. Because the purpose of this study is to value improvements in a functioning system, in the choice sets no classic "no choice" option was included. 
Farmers are currently operating under what can be called a base scenario. The base scenario corresponds to the situation where the price is at the lowest level, duration is 5 years, supply is not guaranteed and licenses are not transferable. Each choice set contains at least one option, which is dominant to this base level with price at the lowest level but one or more of the other attributes at improved levels. The studies by Blamey et al. (1999), Foster and Mourato (2002), Hanley et al. (2006) and Bateman et al. (2006) are other examples of research where the classic "no choice" option is not included, because possible improvements made to some kind of base scenario of a system are studied.

\section{INSERT FIGURE 2 ABOUT HERE}

\section{Data collection}

The data were collected in April 2008 in the Limpopo province of South Africa. This is the province with about $60 \%$ of all smallholder schemes (Denison, 2006). Two regions, where clusters of smallholder irrigation schemes are located were selected: the region around Mafefe and the region around Trichardtsdal (figure 3). Although geographically close to each other these regions are separated by an embranchment of the Drakensbergen mountain range. The difference in cropping patterns between the regions reflects the difference in degree of water scarcity. Within these regions seven irrigation schemes were identified from the national database of small-scale irrigation schemes (Denison, 2006). Both larger irrigation schemes with over 100 farmers and smaller schemes with only 30-40 farmers were included in the sample. In this way a sample typifying the situation of smallholder irrigation schemes in the rural areas of South Africa was established.

\section{INSERT FIGURE .3 ABOUT HERE}

Contacts with the scheme management were made through the agricultural extension services responsible for the schemes. These services also provided a list of all active farmers on the schemes and background information regarding each individual scheme. From the lists, about $30 \%$ of the farmers were randomly selected. These farmers were then contacted through scheme management or 
traditional authorities and all selected farmers were prepared to collaborate. A team of enumerators consisting of $\mathrm{PhD}$ and Master students from Limpopo University in Polokwane was trained to conduct the interviews. During the training there was also one day of pre-testing of the questionnaire. Farmers were interviewed on field. Before starting the questionnaire the purpose of the study was explained and respondents were given information regarding the actual water rights system. In a stepwise manner, they were made familiar with the graphical representation of the attribute levels included in the CR experiment. The questionnaires included not only the CR experiment, but also detailed information regarding farming activities, alternative income sources and institutional aspects of water management. Table 2 gives an overview of some of the respondent specific variables included in the analysis. In total 138 farmers were interviewed, but only 134 questionnaires were completed and could be included in the analyses. These 134 questionnaires provided 402 completed choice sets for analysis.

\section{INSERT TABLE 2 ABOUT HERE}

\section{Results and discussion}

\section{Socio-economic characteristics of sample population}

Detailed information regarding irrigation activities, income sources and institutional aspects of water management was collected. The findings in this section are very similar to that of other studies on smallholder irrigation schemes in South Africa (e.g. Perret, 2002; Van Averbeke and Mohamed, 2007; Hope et al., 2008). This supports our claim that the selected schemes and respondents are typical for the South African context. The average age of the farmers is 58 years, indicating that farming population at this type of irrigation schemes is aging. The average number of years of schooling of the farmers is 5.6 years. Both these figures are typical for this type of irrigation schemes in the South African context, as is the average irrigation plot size of 1.2 ha.

All schemes in the sample are irrigated by surface irrigation, which is the prevailing method at smallholder schemes. In the Mafefe region most farmers only cultivate their irrigated land during the wet summer season, with maize as the most important crop. Around Trichardtsdal production is more 
diversified. Most farmers also produce maize in summer, but they produce a wide variety of crops in winter. Spinach, beans, beetroots, cabbages and tomatoes are the most important winter crops in this region. The income share from irrigated agriculture ranges between $1 \%$ and $100 \%$ with an average of $29 \%$. The two most important income sources for the households in the sample are pensions and child grants. Also consistent with the other studies on smallholder irrigators is the finding that production is mainly for household consumption. The average degree of commercialization, calculated as the value share of production that is marketed, is $38 \%$ in this study.

Farmers were also questioned about the occurrence of water shortages. Figure 4 presents the degree of water shortage. A large majority of the farmers reported that water shortages are sometimes occurring. It has to be noted however that in the winter season (= dry season) $37 \%$ of the farmers reduces their cultivated area, and about the same percentage does not produce. The main reason mentioned for this conduct is lack of sufficient water supply, suggesting that for full utilization of the irrigated area, occurrence of water shortage would probably be significantly higher.

\section{INSERT FIGURE 4 AND 5 ABOUT HERE}

Finally the trust of respondents in water management institutions was monitored. The question format applied in the World Values Survey to measure trust in organizations was used for this purpose (World Values Survey, 2006). The farmers had to indicate on a four-point scale how much confidence they have in the functioning of each institution. Figure 5 provides insight in the trust in the Catchment Management Agency (CMA) and the Department of Water Affairs (DWAF). Notwithstanding the fact that it is a higher-level institution, trust in the functioning of the DWAF is higher than that in the functioning of the CMA. An explanation for this can be that respondents are still less familiar with the CMA and its tasks because it is a new institution created very recently in the context of the 1998 Water Act and because in the Olifants catchment, where both study sites are located, the CMA is still not fully operational. That smallholders are unaware about how the water management institutions work and what their responsibilities are was also reported by Waalewijn et al. (2005) and Orne-Gliemann (2008). 


\section{Rank ordered logit results}

The results of the rank ordered logit models were obtained using the statistical package STATA version 9. Following the recommendations of Holmes and Adamowicz (2003) the two qualitative attributes shown in table 1 were effect coded. When using effect coding, a reference level is assigned code -1 . For the quality of title dimension "non-guaranteed supply" was chosen as reference level, while for the transferability the reference level was "no possibility to transfer". In effects coding the utility of the reference level equals the negative of the sum of the other estimated coefficients, while the other levels take the utilities associated with their coefficient.

Table 3 presents the rank ordered logit estimates for two different model specifications. The first model represents the most basic attribute specification. All the coefficients are significantly different from zero at the $95 \%$ significance level, meaning that they all are significant determinants of choice. The signs of the attribute parameters are as expected. Guarantee of water supply, increased duration of the license and improvements in transferability all increased the probability that an option was chosen. Oppositely, a higher water price decreased the choice probability. This is in line with economic theory.

Model 2 introduces respondent specific variables into the indirect utility function. To arrive at this model we tested several interactions for which there were theoretical or empirical grounds and maintained those that were consistent throughout different model runs. Conform to the general expectations results indicate that the more commercially oriented farmers are, the more importance they attach to the possibility of market transfer. Several authors have described the role that water markets could play in addressing supply risk in regions with fluctuating water supply (Bjornlund 2006, Calatrava and Garrido 2005; Hadjigeorgalis 2008). For South Africa, Pott et al. (2009) describe, based on interviews, how farmers mainly see markets as a way to ensure access to water supply. Obviously this is more important for the commercially oriented farmers than for the farmers who are more subsistence oriented and see irrigated agriculture as a way to supplement their diet. Respondents more dependent on irrigation for their income are more concerned about the quality of the title and are also more concerned about price increases. It is quite logical that the more one's 
income depends on a certain resource, the more importance is attached to the quality of title for that resource. For these farmers the repercussions of insufficient supply are much higher. Moreover in the sample population higher irrigation income shares are usually correlated with lower and less diversified total incomes, a trend also reported by Yokwe (2009). This trend explains the significant interaction found between income share from irrigated agriculture and the price attribute. Another finding is that older respondents seem to attach less importance to price increases. Being more educated has a positive effect on the valuation of the duration of the license, but the effect on valuing quality of the title is opposite. The effect of the "education*duration" interaction term could have its origin in the often found positive relationship between education and investments in productivity. This relationship implies that better educated people are more inclined to make such investments, but as explained by Backeberg (2006) such investment decisions are negatively affected by a short duration of the licenses. A possible explanation for the interaction between education and quality of title is that the more educated people are, the more they consider themselves capable of dealing with non-guaranteed water supply by adjusting for instance cropping patterns. Cannon et al., (2003) for instance claim that better educated people can stimulate more mitigation choices to improve their circumstances. Furthermore the more educated farmers usually have supplementary income sources. As expected being more prone to water shortage increases concerns about quality of title. For farmers who never experience water shortage guaranteed supply obviously is less of an issue. Similar findings were reported by Alcon et al. (2008), Rigby et al. (2010) and Barton and Bergland (2010). Having more trust in the institutions responsible for water management finally decreases the importance attached to the duration of the license. It should be noted however that the "trust*duration" interaction was just not significant at a $90 \%$ level.

\section{INSERT TABLE 3 ABOUT HERE}

A second major purpose of the CR experiment was to obtain the implicit values of marginal attribute changes. Table 4 presents the estimates of the implicit prices derived from model 2 for average respondents in terms of the individual specific characteristics. As expected these values are clearly lower than the productive value of water of $0.5 \mathrm{R} / \mathrm{m}^{3}$ estimated by Speelman et al. (2008b). 
Theoretically water transfers are expected to facilitate water reallocation from low to high valued uses at low cost, creating surpluses both for sellers and buyers (Brooks and Harris, 2008). Another potential advantage is that markets empower individual users to manage supply uncertainty incorporating decentralized information (Hadjigeorgalis, 2008). The WTP results indicate that in our study the opportunity to transfer water licenses is highly valued, but for the small-scale irrigators in the sample installing water markets as compared to a system of administrative transfer does not seem to add much value. Nevertheless Rosegrant et al. (1995), Shi (2006) and Donohew (2009) warned that over-regulation of water transfers will reduce their efficiency gains. An additional point that has to be considered here is to which extent water markets can decrease the administrative burden and associated costs of the currently proposed agency based transfer.

High importance furthermore is attached to secured water supply. A similar result was also found by Alcon et al. (2008) and Rigby et al. (2010). They found that farmers would be willing to pay considerably more (up to 2 times more) for more certain water supply. In addition, the results suggest that increasing the review period of the licenses is an interesting intervention, since apart from the economic gain reported in table 6.4 , this would certainly decrease administrative costs. This positive effect should be weighed against the loss in flexibility to adjust water policy when long-term licenses are in place. Hodgson (2006) discusses this trade-off in more detail.

\section{INSERT TABLE .4 ABOUT HERE}

\section{Conclusions}

As competition for water grows across the globe, water users and water management organizations seek better institutional arrangements for coordinating use and resolving conflicts (Bruns et al., 2005b; Comprehensive Assessment of Water Management in Agriculture, 2007). Improved water rights are one option to increase water productivity, to raise benefits from existing and new investments in water use and enhance rural livelihoods. The estimation of how inefficient a current water rights system is or what the impact of different improvements could be, has so far received little attention in literature (Linde-Rahr, 2008). 
This study demonstrates that contingent ranking (CR) is a promising tool to measure the effect of improving water rights along different dimensions. It is applied to the case of smallholder irrigators in South Africa. While this sector is considered important for poverty reduction in rural areas, it clearly struggles with problems of low water use efficiency and insufficient cost recovery. Taking into account this context it is highly relevant to evaluate the expected impact of water right reforms on this specific stakeholder. Overall the estimations of the WTP indicate that farmers experience significant inefficiencies in the current water rights system, with significant economic gains attached to the improvement of the water rights. Tackling these inefficiencies will not only be favorable for the efficiency of water use of smallholder irrigators, but given the size of the benefits, it can also add significantly to the government objective of cost recovery. With a higher WTP for water there is more room for government to increase water prices and reach a higher level of cost recovery.

Policy makers can clearly use such results to guide water right reforms. Besides the information on the economic gains, it gives them direct information concerning the priorities of a target group. This knowledge can help government to increase support for the interventions. A limitation of the current study is that it focused on the average smallholder, while this actually is a quite heterogeneous population. In a second paper (Speelman et al., 2010) we therefore investigate in depth the heterogeneity in preferences along different population segments. Given the South African context it would in the future also be interesting to collect data from the large scale commercial farmers or from other water using sectors (mining, forestry) and to compare the results.

Finally it should be stressed that when deciding on reforms the cost side should also be taken into account. While this study focuses on the farmers and how their transaction costs can be lowered by water rights reforms, Challen (2002) and McCann and Easter (2004) have stressed that there is also a cost of institutional change itself and of establishing and maintaining institutions. For government some reforms, like for instance the increase of the review period, might lower costs, while others will have a price tag attached to them. The analysis provided in this study should therefore be used as a part of a broader framework. 


\section{Acknowledgements}

The corresponding author is funded as postdoctoral researcher by the Research Foundation Flanders (FWO).

\section{Literature cited}

Alcon, F., Rigby, D., Burton, M. and M. Dolores de Miguel, 2008. Supply Uncertainty and the Value of Irrigation Water in Southern Spain. Paper presented at $1^{\text {st }}$ EAAE workshop on Valuation Methods in Agro-food and Environmental Economics: State of the Art and Future Challenges in Stated Choice Experiments, Barcelona, Spain, 3-4 July 2008

Alriksson, S. and T. Öberg, 2008. Conjoint Analysis for Environmental Evaluation: A Review of Methods and Applications. Env Sci Pollut Res 15 : 244-257, doi:10.1065/espr2008.02.479

Backeberg G, 2006. Reform of User Charges, Market Pricing and Management of Water: Problem or Opportunity for Irrigated Agriculture? Irrigation and Drainage 55: 1-12, doi:10.1002/ird.221

Barton, D.N. and O. Bergland, 2010. Valuing irrigation water using a choice experiment: an 'individual status quo' modeling of farm specific water scarcity. Environmental and development economics 15 (3) 321-340.

Bateman, I.J., Cole, M.A., Georgiou, S. and D.J. Hadley, 2006. Comparing Contingent Valuation and Contingent Ranking: a Case Study Considering the Benefits of Urban River Water Quality Improvements. Journal of Environmental Management 79(3): 221-231, doi:10.1016/j.jenvman.2005.06.010

Beggs, S., Cardell, S. and J. Hausman, 1981. Assessing the Potential Demand for Electric Cars. Journal of Econometrics 16: 1-19

Bennett, J. and V. Adamowicz, 2001. Some Fundamentals of Environmental Choice Modeling. In: The Choice Modelling Approach to Environmental Valuation, Jeff Bennett and Russell Blamey (eds). Edward Elgar, Cheltenham, UK

Bjornlund, H., 2006. Can water markets assist irrigators managing increased supply risk? Some Australian Experiences. Water International 31: 221-232. 
Blamey, R., Gordon, J. and R. Chapman, 1999. Choice Modelling: Assessing the Environmental Values of Water Supply Options. The Australian Journal of Agricultural and Resource Economics 43(3): 337-357

Brooks, R. and E. Harris, 2008. Efficiency gains from water markets: empirical analysis of Watermove in Australia. Agricultural water management 95, 391-399.

Bruns, B., 2006. Reconstituting Water Rights: Pathways for Polycentric Praxis. Paper presented at Survival of the Commons: Mounting Challenges and New Realities, International Association for the Study of Common Property, Bali, Indonesia, 19-23 June 2006

Bruns, B, Ringler, C and R. Meinzen-Dick, 2005a. Introduction. In: Water Rights Reform: Lessons for Institutional Design, Bryan Bruns et al (eds). IFPRI, Washington, USA

Bruns, B, Ringler, C and R. Meinzen-Dick, 2005b. Chapter 12: Reforming Water Rights: Governance, Tenure, and Transfers. In: Water Rights Reform: Lessons for Institutional Design, Bryan Bruns et al (eds). IFPRI, Washington, USA

Bruns B and R. Meinzen-Dick, 2005. Frameworks for Water Rights: An Overview of Institutional Options. In: Water Rights Reform: Lessons for Institutional Design, Bryan Bruns et al (eds). IFPRI, Washington, USA

Bruns, B., 2007. Irrigation Water Rights: Options for Pro-poor Reform. Irrigation and drainage 56: 237-246, doi: 10.1002/ird.314

Bruns, B., 2003. Water Rights: a Synthesis Paper on Institutional Options for Improving Water Allocation. Paper presented at International working conference on water rights: institutional options for improving water allocation, Hanoi, Vietnam, 12-15 February 2003

Burgess, L. and D.J. Street, 2005. Optimal Designs for Choice Experiments with Asymmetric Attributes. Journal of Statistical Planning and Inference 134: 288-301, doi:10.1016/j.jspi.2004.03.021

Burton, M., Marsh, S. and J. Patterson, 2007. Community Attitudes Towards Water Management in the Moore Catchment, Western Australia. Agricultural systems 92: 157-178, doi:10.1016/j.agsy.2006.03.004

Calatrava, J. and A. Garrido, 2005. Spot water markets and risk in water supply. Agricultural Economics 33: 131-143. 
Cannon, T., Twigg, J. and J. Rowell, 2003. Social Vulnerability, Sustainable Livelihoods and Disasters. Report to DFID Conflict and Humanitarian Assistance Department (CHAD) and Sustainable Livelihoods Office, London.

Challen, R., 2000. Institutions, Transaction Costs, and Environmental Policy: Institutional Reform for Water Resources. Edward Elgar, Cheltenham, UK

Challen, R., 2002. Economic Analysis of Alternative Institutional Structures for Governance of Water Use. In: Brennan, D., (ed.) Water policy reform: lessons from Asia and Australia. Proceedings of an International workshop held in Bangkok, Thailand, 8-9 June 2001. ACIAR Proceedings No 106, 322p.

Crase, L. and B. Dollery, 2006. Water Rights: a Comparison of the Impacts of Urban and Irrigation Reforms in Australia. The Australian Journal of Agricultural and Resource Economics 50(3): 451462, doi:10.1111/j.1467-8489.2006.00358.x

Denison, J., 2006. Data base on Smallholder Irrigation Schemes in South Africa. WRC Project No. K5//1463/4. Water Research Commission, Pretoria, South Africa

Donohew, Z., 2009. Property rights and western United States water markets. The Australian Journal of Agricultural and Resource Economics 53: 85-103

DWAF 2008a. WMA charges 2008. Department of Water Affairs and Forestry, Republic of South Africa, Pretoria, South Africa.

DWAF 2008b. Approved Raw Water Charges - 2008/09, National Water Resource Infrastructure. Department of Water Affairs and Forestry, Republic of South Africa, Pretoria, South Africa.

DWAF 2004. National Water Resources Strategy Paper of South Africa. Department of Water Affairs and Forestry, Republic of South Africa, Pretoria, South Africa.

Easter, K.W., Rosegrant, M.W. and A. Dinar 1998. Markets for water: Potential and performance. Kluwer, New York.

Foster, V. and S. Mourato, 2002. Testing for Consistency in Contingent Ranking Experiments. Journal of Environmental Economics and Management 44: 309-328, doi:10.1006/jeem.2001.1203

Foster, V. and S. Mourato, 1997. Behavioural Consistency, Statistical Specification and Validity in the Contingent Ranking Method: Evidence from a Survey on the Impacts of Pesticide Use in the U.K. CSERGE Working Paper GEC 97-09. 
Frija, A., Chebil, A., Speelman, S. and G. Van Huylenbroeck, 2008. Effect of Changes in the Institutional Structure of Irrigation Water Property Rights on the Willingness to Pay of Farmers for Water. In: Proceedings of the XIIth EAAE Congress: People, Food and Environments: Global Trends and European Strategies, Ghent, Belgium, 26-29 August 2008.

Gillit, C.G., Nieuwoudt, W.L. and G.R. Backeberg, 2005. Water Markets in the Lower Orange River Catchment of South Africa. Agrekon 44: 363-382.

Hadjigeorgalis, E., 2008. Managing drought through water markets: farmer preferences in the Rio Grande Basin. Journal of the American Water Resources Association 44: 594-605.

Hanemann, W.M. and B. Kanninen, 1999. Statistical Analysis of Discrete-Response CV Data. In: Valuing Environmental Preferences: Theory and Practice of the Contingent Valuation Method in the US, EU, and Developing Countries, Ian J. Bateman and Kenneth G. Willis (eds). Oxford University Press, New York.

Hanley, N., Colombo, S., Tinch, D., Black, A. and A. Aftab, 2006. Estimating the Benefits of Water Quality Improvements under the Water Framework Directive: Are Benefits Transferable? European Review of Agricultural Economics 33 (3): 391-413, doi:10.1093/eurrag/jbl019

Hanley, N., Mourato, S. and R. Wright, 2001. Choice Modelling Approaches: a Superior Alternative for Environmental Valuation. Journal of economic surveys 15: 435-462, doi:10.1111/14676419.00145

Hanley, N., Wright, R.E. and V.L. Adamowicz, 1998. Using Choice Experiments to Value the Environment. Environmental and Resource Economics 11(3-4): 413-428.

Heltberg, R., 2002. Property Rights and Natural Resource Management in Developing Countries. Journal of Economic Surveys 16: 189-214, doi:10.1111/1467-6419.00164

Herrera; P., Van Huylenbroeck, G. and R. Espinel, 2004. An Application of the Contingent Valuation Method to Assess the Efficiency of the Institutional Structure of Irrigation Property Rights: the Case of the Peninsula of Santa Elena. International Journal of Water Resource Development 20(4): 537-551, doi: 10.1080/07900620412331319171

Hodgson, S., 2006. Modern water rights, Theory and practice. FAO Legislative Study 92, FAO, Rome, 2006 
Holmes, T.P and V.L. Adamowicz, 2003. Attribute-based Methods. In: A Primer on Non-Market Valuation, Patricia Champ et al. (Eds). Kluwer, Dordrecht, The Netherlands

Hope, R.A., Gowing, J.W. and G.P.W. Jewitt, 2008. The Contested Future of Irrigation in African Rural Livelihoods-analysis from a Water Scarce Catchment in South Africa. Water Policy 10: 173192, doi:10.2166/wp.2008.061

Linde-Rahr, M., 2008. Willingness to Pay for Forest Property Rights and the Value of Increased Property Rights Security. Environ Resource Econ 41: 465-478, doi: 10.1007/s10640-008-9202-3

Louw, D.B. and H.D. van Schalkwyk, 2002. Efficiency of Water Allocation in South Africa: Water Markets as an Alternative. Paper presented at the Irrigation Water Policies: Micro and Macro Considerations Conference, Agadir, Morocco, 15-17 June 2002

MacKenzie, J., 1993. A Comparison of Contingent Preference Models. American Journal of Agricultural Economics 75(3): 593-603.

McCann, L., Easter, W.K., 2004. A framework for estimating the transaction costs of alternative mechanisms for water exchange and allocation. Water Resources Research. 40, W09S09

McFadden, D., 1974. Conditional Logit Analysis of Qualitative Choice Behaviour. In: Frontiers in Econometrics, Paul Zarembka (ed). Academic Press, New York

Matthews, O.P., 2004. Fundamental Questions About Water Rights and Market Reallocation. Water Resour. Res., 40, W09S08, doi:10.1029/2003WR002836.

Nieuwoudt, W.L. and R.M Armitage, 2004. Water Market Transfers in South Africa: Two Case studies. Water Resour. Res., 40, W09S05, doi:10.1029/2003WR002840

Nieuwoudt, W.L.,2002. Water Market Institutions in South Africa, Lessons from Colorado. Paper presented at the Conference on Irrigation Water Policies: Micro and Macro Consideration, Agadir, Marocco, 15-17 June 2002

Nixon, H., Saphores, J-DM., Ogunseitan, O.A. and A. Shapiro, 2009. Understanding Preferences for Recycling Electronic Waste in California. Environment and Behavior 41(1): 101-124, doi:10.1177/0013916507310053

Orne-Gliemann, M., 2008. Water users' associations from the users` perspective: local water management at Thabina irrigation scheme, Limpopo, South Africa. Journal for Transdisciplinary Research in Southern Africa 4: 1-29 
Ostrom, E., 2000. Private and Common Property Rights. In: Encyclopedia of Law and Economics, Vol.II: Civil Law and Economics, Boudewijn Bouckaert and Gerrit De Geest (eds). Edward Elgar, Celtenham, UK

Paudel, K.P., Dunn, M.A., Bhandari, D., Vlosky, R.P. and K.M. Guidry, 2007. Alternative Methods to Analyze the Rank Ordered Data: a Case of Invasive Species Control. Natural Resource Modeling 20(3): 451-471.

Perret, S., 2002. Water Policies and Smallholding Irrigation Schemes in South Africa: A History and New Institutional Challenges. Water Policy 4(3): 283-300.

Perret, S., Geyser, M., 2007. The Cost of Irrigation: Adapting Existing Guidelines to Assess the Full Financial Costs of Irrigation Services: The Case of Smallholder Schemes in South Africa. Water SA 33: $67-78$

Pott, A., Versfeld, K., van Rooyen, M. and A. Muir, 2009. A scoping exercise to investigate the potential need for, and nature of, water trading in South Africa. WRC Report No KV 222/09, Water Research Commission, Pretoria, South Africa

Randall, A., 1978. Property Institutions and Economic Behavior. Journal of Economic Issues 12: 121

Republic of South Africa 1998. National Water Act. Republic of South Africa, Pretoria South Africa Rigby, D., Alcon, F. And M. Burton, 2010. Supply uncertainty and the economic value of irrigation water. European Review of Agricultural Economics 37(1), 97-117.

Rosegrant, M.W. and H.P. Binswanger1994. Markets in tradable water rights: potential for efficiency gains in developing country water resource allocation. World. Development, 22:1613-1625.

Rosegrant, M.W., Schleyer, R.G. and S.N. Yadav, 1995. Water policy for efficient agricultural diversification: market-based approaches. Food Policy 20: 203-223

Scott, A., 1989. Conceptual Origins of Rights Based Fishing. In Rights Based Fishing, edited by Neher, P.A. et al., Dordrecht: Kluwer

Shi, T., 2006. Simplifying complexity: rationalizing water entitlements in the Southern Connected River Murray System, Australia. Agricultural Water Management 86, 229-239. 
Speelman, S., D’Haese, M., Buysse, J. and L. D’Haese, 2008a. A Measure for the Efficiency of Water Use and its Determinants, Study at Small-scale Irrigation Schemes in North-West Province, South Africa. Agricultural Systems 98(1): 31-39, doi:10.1016/j.agsy.2008.03.006

Speelman, S., Farolfi, S., Perret, S., D'Haese, L. and M. D'Haese, 2008b. Irrigation Water Value at Small-scale Schemes: Evidence from the North-West Province, South Africa. International Journal of Water Resources Development 24(4): 621-633, doi:10.1080/07900620802224536

Speelman, S., Farolfi, S., Frija, A., D’Haese, M., D’Haese, L., 2010. The impact of the water rights definition on smallholder irrigators' willingness to pay for water in Limpopo province, SouthAfrica. Environment and Development Economics (In press): doi:10.1017/S1355770X10000161

Stein, R., 2005. Water law in a democratic South Africa: a country case study examining the introduction of a public rights system. Texas Law Review 83: 2167- 2183.

Street, D.J., Burgess, L. and J. Louviere, 2005. Quick and Eeasy Choice Sets: Constructing Optimal and Nearly Optimal Stated Choice Experiments. Intern. Journal of Research in Marketing 22: 459470

Van Averbeke, W. and S.S. Mohamed, 2006. Smallholder Irrigation Schemes in South Africa: Past, Present, and Future. Paper presented at the $2^{\text {nd }}$ Symposium of the SANCID:The Changing Face of Irrigation in South Africa, Mpumalanga, South Africa, 15-17 November 2006

Virjee, K. and S. Gaskin, 2005. Fuzzy Cost Recovery in Planning for Sustainable Water Supply Systems in Developing Countries. Energy 30, 1329-1341, doi: 10.1016/j.energy.2004.02.021

Waalewijn, P., Wester, P. and K. van Straaten, 2005. Transforming river basin management in South Africa - Lessons from the Lower Komati River. Water International 30: 184-196.

World Values Survey, 2006. WVS 2005 Questionnaire. http://www.worldvaluessurvey.org/wvs/articles/folder_published/survey_2005. Accessed July 2010.

Yokwe, S., 2009. Water productivity in smallholder irrigation schemes in South Africa. Agricultural Water Management 96: 1223-1228.

Zekri, S. and K.W. Easter, 2007. Water Reforms in Developing Countries: Management Transfers, Private Operators and Water Markets. Water Policy 9(6): 573-589, doi: 10.2166/wp.2007.127 


\section{TABLES}

Table 1 Attributes and levels used in the choice sets

\begin{tabular}{lccc}
\hline Attributes & \multicolumn{2}{c}{ Levels } \\
\hline Transferability & not transferable & agency based transfer & market transfer \\
Duration & 5 year & 10 year & \\
Quality of title & guaranteed quantity & quantity not guaranteed & \\
Price & $0.06 \mathrm{R} / \mathrm{m}^{3}$ & $0.09 \mathrm{R} / \mathrm{m}^{3}$ & $0.12 \mathrm{R} / \mathrm{m}^{3}$ \\
\hline
\end{tabular}


Table 2 Definition of respondent specific variables included in the rank ordered logit model

\begin{tabular}{|c|c|c|c|c|}
\hline Name & Definition & Description & $\begin{array}{l}\text { Mean } \\
\text { (st.dev) }\end{array}$ & Range \\
\hline com & $\begin{array}{l}\text { Degree of } \\
\text { commercialization }(\%)\end{array}$ & $\begin{array}{l}\text { Share of irrigated production } \\
\text { marketed (in terms of value) }\end{array}$ & $38(30)$ & $0-100$ \\
\hline iryshare & $\begin{array}{l}\text { Income dependency on } \\
\text { irrigation }(\%)\end{array}$ & $\begin{array}{l}\text { Share of household income } \\
\text { from irrigation }\end{array}$ & $29(24)$ & $1-100$ \\
\hline age & Age of farmer & & $57.8(13.2)$ & $27-85$ \\
\hline edu & \multicolumn{2}{|c|}{ Years of schooling of farmer } & $5.6(4.5)$ & $0-15$ \\
\hline insttrust & Institutional trust & $\begin{array}{l}\text { Summated score for trust in } \\
\text { water management institutions. } \\
\text { A four-point scale ranging } \\
\text { from "no confidence at all" to } \\
\text { "a great deal of confidence" } \\
\text { was used to assess trust in the } \\
\text { catchment management agency } \\
\text { and the department of water } \\
\text { affairs. }\end{array}$ & & \\
\hline short & $\begin{array}{l}\text { Frequency of water } \\
\text { shortage }\end{array}$ & $\begin{array}{l}\text { Five point scale assessing } \\
\text { frequency of occurrence of } \\
\text { water shortage, ranging from } 1 \\
\text { "often" to } 5 \text { "never" }\end{array}$ & & \\
\hline
\end{tabular}


Table 3 Rank ordered logit results: determinants of ranking

\begin{tabular}{|c|c|c|c|c|c|c|}
\hline \multirow[b]{2}{*}{ Attribute } & \multicolumn{3}{|c|}{ Model 1} & \multicolumn{3}{|c|}{ Model 2} \\
\hline & coefficient & SE & p-value & coefficient & SE & p-value \\
\hline Duration & 0.0957 & 0.0136 & 0.000 & 0.1152 & 0.0408 & 0.005 \\
\hline Quality of title & 0.6284 & 0.0382 & 0.000 & 1.1495 & 0.2850 & 0.000 \\
\hline Price & -0.0478 & 0.0147 & 0.001 & -0.1746 & 0.0857 & 0.042 \\
\hline Agency based transfer & 0.2300 & 0.0496 & 0.000 & 0.2386 & 0.0487 & 0.000 \\
\hline Market transfer & 0.3598 & 0.0514 & 0.000 & 0.2157 & 0.0732 & 0.003 \\
\hline Com*market transfer & & & & 0.3746 & 0.1527 & 0.014 \\
\hline Iryshare*quality of title & & & & 0.8666 & 0.4306 & 0.044 \\
\hline Iryshare*price & & & & -0.1267 & 0.0698 & 0.069 \\
\hline Age*price & & & & 0.0028 & 0.0013 & 0.036 \\
\hline Edu*quality of title & & & & -0.0577 & 0.0192 & 0.003 \\
\hline Edu*duration & & & & 0.0064 & 0.0029 & 0.030 \\
\hline Insttrust*duration & & & & -0.0109 & 0.0068 & 0.111 \\
\hline Short*quality of title & & & & -0.1155 & 0.0656 & 0.079 \\
\hline \multicolumn{7}{|l|}{ Model statistics } \\
\hline LogL(initial) & -1277.58 & & & -1277.58 & & \\
\hline $\operatorname{LogL}$ (final) & -1051.47 & & & -1029.65 & & \\
\hline Pseudo $\mathrm{R}^{2}$ & 0.177 & & & 0.194 & & \\
\hline
\end{tabular}


Table 4 Valuation of attribute changes

\begin{tabular}{lc}
\hline Attribute change & Implicit WTP \\
\hline No transfer to agency based transfer & $14.6 \mathrm{c} / \mathrm{m}^{3}$ \\
Agency based transfer to market transfer & $2.4 \mathrm{c} / \mathrm{m}^{3}$ \\
No secured supply to secured supply & $12.6 \mathrm{c} / \mathrm{m}^{3}$ \\
5 years to 10 years & $9.7 \mathrm{c} / \mathrm{m}^{3}$ \\
\hline
\end{tabular}




\section{FIGURES}

Full factorial design 36 options

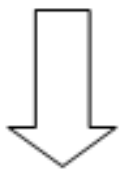

Orthogonal design

9 options

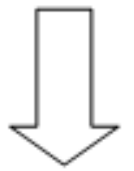

9 choice sets of 4 options

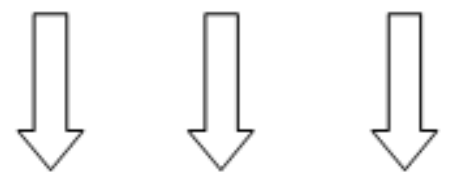

3 blocks of 3 choice sets
Orthogonal design software (Spss Orthoplan)
Technique of systematic level changes (Street et al., 2005)

Division in blocks

Figure 1 Procedure of designing ranking sets 


\begin{tabular}{|c|c|c|c|c|}
\hline Attributes & Option 1 & Option 2 & Option 3 & Option 4 \\
\hline Transferability & $\frac{6}{k}$ & & + & $x \longleftrightarrow$ \\
\hline Duration & 5 years & 10 years & 10 years & 5 years \\
\hline Quality of title & & & & \\
\hline Price & $12 \mathrm{c} / \mathrm{m}^{3}$ & $6 \mathrm{c} / \mathrm{m}^{3}$ & $9 \mathrm{c} / \mathrm{m}^{3}$ & $12 \mathrm{c} / \mathrm{m}^{3}$ \\
\hline Rank & & & & \\
\hline
\end{tabular}

Figure 2 Choice set example

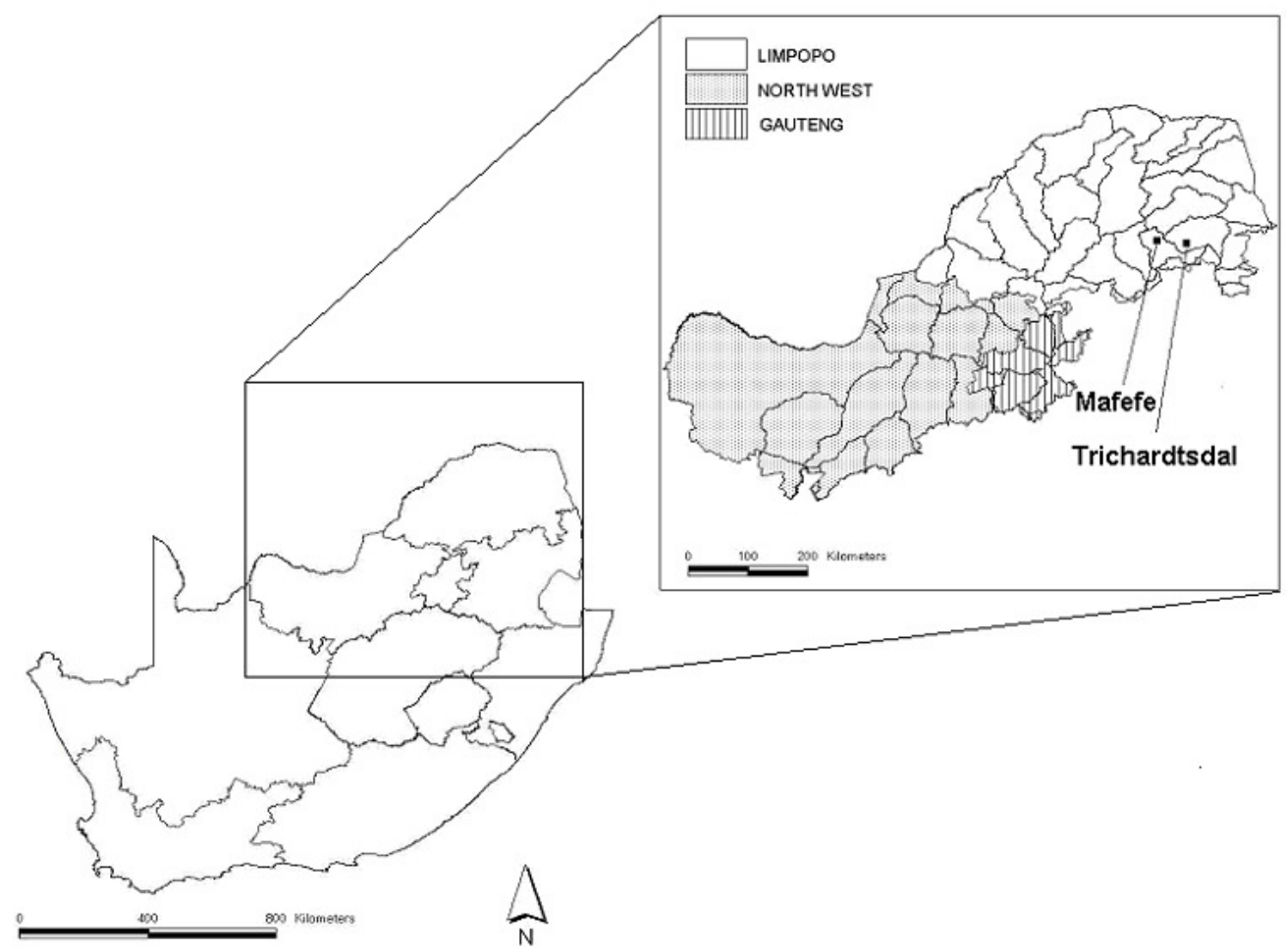

Figure 3 Situation of the selected regions within South Africa 


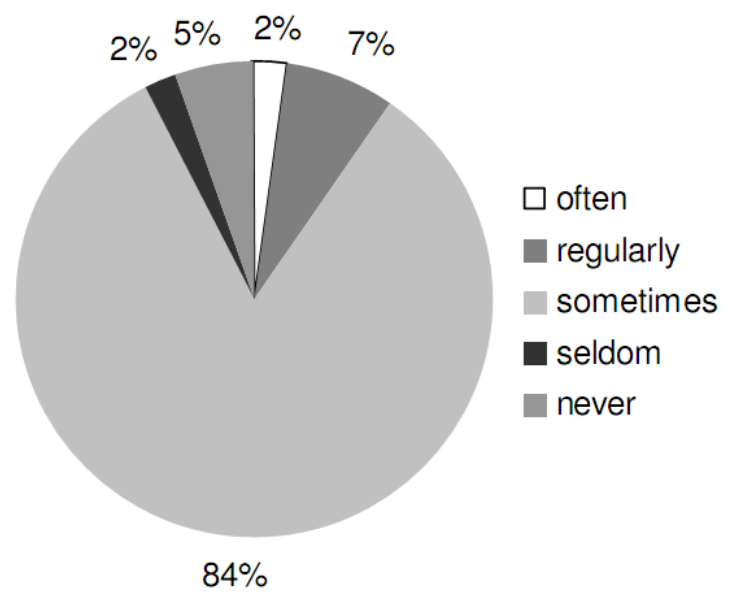

Figure 4 Stated occurrence of water shortage

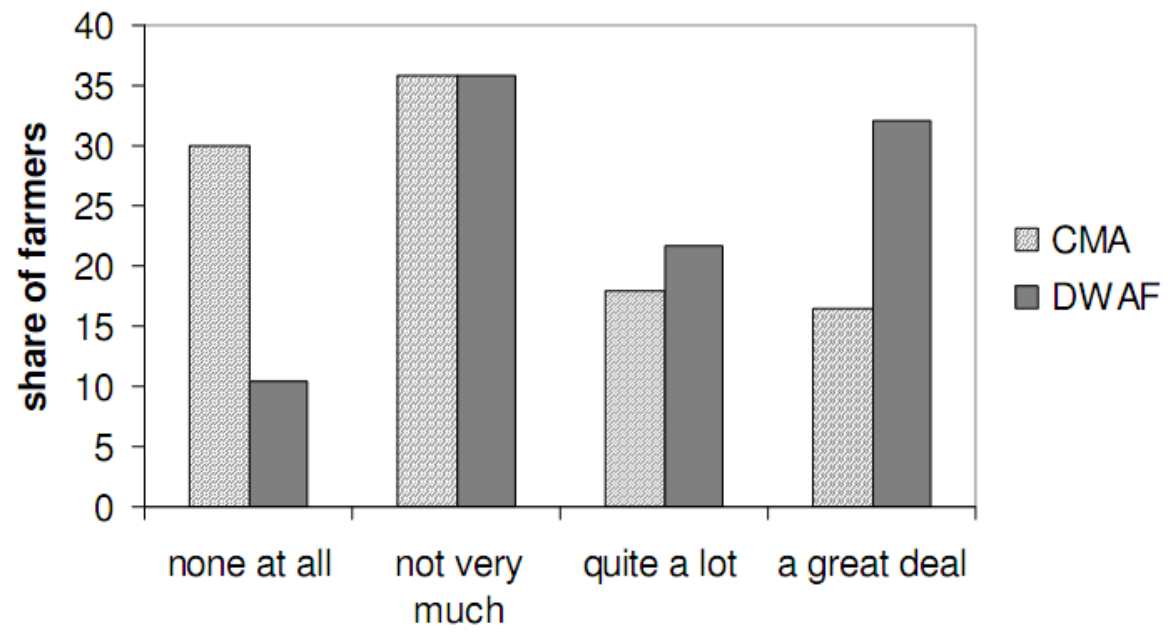

Figure 5 Confidence levels in water management institutions 